\title{
SASARAN DAN PENDAYAGUNAAN ZAKAT SERTA PENGARUHNYA TERHADAP PENGENTASAN KEMISKINAN
}

\author{
AKMAL \\ STAI AL-Azhar Gowa Prodi Ekonomi Syari’ah \\ E-mail: akmalruhalipa02@gmail.com
}

\begin{abstract}
Zakat merupakan salah satu solusi alternatif untuk mengurangi kemiskinan. hasil studi lapangan menunjukkan bahwa manfaat zakat yang disalurkan cukup baik, namun belum optimal. Meskipun dari tahun ke tahun meningkatkan zakat namun realisasinya masih kurang dari potensi zakat yang ada. Jurnal ini ditulis bertujuan untuk mengetahui tingkat potensi hubungan dan pengaruhnya terhadap peran zakat kepada fakir miskin. Setelah data terkumpul, penulis menganalisis dan menginterpretasikan kesimpulan yang dihasilkan. Dari data-data yang diperoleh maka dapat disimpulkan bahwa sebagian besar masyarakat setuju dengan distribusi dan pemanfaatan zakat, disertai dengan pelatihan dan keterampilan yang diberikan untuk meningkatkan kemajuan usaha. Konsepsi pemberdayaan ekonomi umat melalui pengamalan ibadah zakat yang diajarkan dalam Islam merupakan salah satu alternatif yang dapat ditempuh dalam mengatasi masalah sosial. Potensi zakat yang sangat signifikan tersebut perlu digali secara optimal agar dapat digunakan untuk ikut menggerakkan perekonomian umat disamping potensi-potensi lain sehingga taraf hidup umat menjadi terangkat. Karena itu kegiatan-kegiatan yang mengarah pada sosialisasi sadar zakat dan yang menjadikan Badan atau Lembaga Amil Zakat lebih profesional, amanah dan mandiri perlu terus digalakkan. Disamping itu harus ditumbuhkan desa-desa binaan zakat dan kegiatan-kegiatan lainnya sebagai salah satu contoh konkrit dari pengelolaan zakat. Pertama, Pendayagunaan zakat berarti bagaimana dana zakat yang telah terhimpun bisa memberikan multimanfaat bagi Mustahiq. Artinya zakat berorientasi terhadap usaha-usaha yang sifatnya produktif dan zakat juga dapat dimanfaatkan untuk memenuhi kebutuhan yang sifatnya jangka pendek. Kedua, Pendayagunaan zakat yang berbasis pengembangan ekonomi, diarahkan pada usaha ekonomi yang sifatnya produktif. Sehingga, diharapkan dapat menghasilkan pendapatan yang bisa mengangkat taraf kesejahteraan bagi ummat.
\end{abstract}

Keyword: Zakat, Kemiskinan, Manfaat Zakat

\section{Pendahuluan}

(Amalia, 1999) Kemiskinan merupakan masalah besar dan sejak lama telah ada, dan hal ini menjadi kenyataan di dalam kehidupan. Islam memandang bahwa masalah kemiskinan adalah masalah tidak terpenuhinya kebutuhan-kebutuhan primer secara menyeluruh. Syariat Islam telah menentukan kebutuhan primer itu (yang menyangkut eksistensi manusia) berupa tiga hal, yaitu sandang, pangan, dan papan. 
Islam mempunyai perhatian yang tinggi utuk melepaskan orang miskin dan kaum dhuafa dari kemiskinan dan kelatarbelakangan. Islam sangat konsisten dalam mengentas kemiskinan, Islam sungguh memiliki konsep yang sangat matang untuk membangun keteraturan sosial berbasis saling menolong dan gotong royong. Yang kaya harus menyisihkan sebagian kecil hartanya untuk yang miskin dan golongan lainnya. Pemberian tersebut dapat berupa zakat, infaq dan sedekah.

(Amalia, 1999) Mengeluarkan zakat merupakan kewajiban bagi setiap muslim yang mampu dan telah memenuhi syarat dengan ketentuan syari'at Islam. Bahkan salah satu rukun Islam yang lima. Tidak dapat di pungkiri bahwa zakat sangat berpotensi sebagai sarana yang efektif memberdayakan ekonomi umat. Allah SWT sudah menentukan rezeki bagi tiap-tiap hambanya, sebagian diberikan rezeki yang lebih dibandingkan sebagian yang lain bukan untuk membeda-bedakan. Tetapi kelompok yang diberikan rezeki yang lebih memiliki tanggung jawab untuk membantu kelompok lain yang kekurangan secara Islam melalui zakat, infaq, dan sedekah. Allah SWT dengan tegas menetapkan adanya hak dan kewajiban antar 2 kelompok di atas (kaya dan miskin) dalam pemerataan distribusi harta kekayaan, yaitu dengan mekanisme zakat, sehingga keseimbangan kehidupan sosial manusia itu sendiri akan tercapai serta akan menghapus rasa iri dan dengki yang mungkin timbul dari kelompok yang kurang mampu. Selain itu di dalam harta orang-orang kaya sesungguhnya terdapat hak orang-orang miskin. Zakat bukanlah masalah pribadi yang pelaksanaannya diserahkan hanya atas kesadaran pribadi, zakat merupakan hak dan kewajiban.

System ekonomi islam memberikan satu instrument agar harta bisa terdistribusi dengan baik dan mengurangi kesenjangan kesejahteraan, yaitu dengan memungut zakat dari orangorang mampu dalam hal ini disebut muzakki kemudian menyalurkannya kepada orang-orang yang berhak menerimanya yang kemudian disebut mustahik zakat.

Zakat dalam konteks umat merupakan salah satu sumber dana potensial dan sangat penting yang ditarik dari kaum yang memiliki kekayaan yang telah mencapai batas ukuran yang ditentukan. Besarnya zakat yang harus dikeluarkan ditentukan berdasarkan jenis dan sifatH dari sumber perolehan kekayaan tersebut. Dalam bidang ekonomi, zakat mencegah penumpukan kekayaan yang mengerikan dalam tangan segelintir orang dan memungkinkan kekayaan untuk disebarkan sebelum sempat menjadi besar dan sangat berbahaya dari tangan pemiliknya. Zakat mempunyai peranan yang sangat penting dalam system perekonomian Islam, karena zakat bisa dijadikan sumber dana bagi menciptakan pemerataan kehidupan ekonomi masyarakat Islam.

(Handayani, 2020) Pada hakikatnya, jika zakat hendak didorong untuk mengentaskan kemiskinan harus ada perhatian terhadap pola distribusi. Zakat harus lebih porsinya untuk kegiatan-kegiatan yang bersifat produktif hal inilah yang dalam bahasa manajemen zakat disebut pendayagunaan. Secara umum, pendayagunaan zakat dilihat dari segi distribusinya terbagi atas dua yaitu, distribusi zakat konsumtif dan distribusi zakat produktif. Sebagaimana telah dijelaskan bahwa penyaluran/pendistribusian zakat konsumtif kurang efektif dalam mengurangi kemiskinan sebab hanya bertahan dalam jangka pendek sehingga pendayagunaan zakat kurang optimal. Namun metode penyaluran zakat oleh lembaga atau badan amil zakat semakin berkembang yaitu metode distribusi zakat produktif. Adapun pendistribusian zakat produktif dilakukan dengan memberikan modal usaha kepada mustahik. Pola pendistribusian 
zakat produktif ada dua, yaitu distribusi produktif tradisional dan distribusi produktif kreatif. Adapun zakat yang didistribusikan untuk kegiatan produktif ini adalah zakat maal.

(Handayani, 2020) Pada pasal 27 UU No. 23 Tahun 2011, zakat dapat didayagunakan untuk usaha produktif dalam rangka pengentasan fakir miskin dan peningkatan kualitas umat. Pendayagunaan zakat untuk usaha produktif dilakukan apabila kebutuhan dasar mustahik telah terpenuhi. Usaha produktif adalah kegiatan yang diperuntukan bagi usaha yang bersifat jangka menengah-panjang. Dampak dari kegiatan produktif ini umumnya masih bisa dirasakan walau dana zakat yang diberikan sudah habis terpakai.

Dan secara yuridis formal keberadaan zakat diatur dalam UU No. 38/1999 tentang pengelolaan zakat yang bertujuan untuk membantu golongan fakir dan miskin, untuk mendorong terlaksananya undang-undang ini pemerintah telah memfasilitasi melalui Baznas dan Bazda yang bertugas untuk mengelola zakat, infaq, dan sedekah.

Badan Amil Zakat Nasional (BAZNAS) merupakan badan resmi dan satu-satunya yang dibentuk oleh pemerintah berdasarkan keputusan Presiden RI No. 8 Tahun 2011 yang memiliki tugas dan fungsi menghimpun dan menyalurkan zakat, infaq dan sedekah (ZIS) pada tingkat nasional. Lahirnya undang-undang Nomor 23 Tahun 2011 tentang pengelolaan zakat semakin mengukuhkan peran BAZNAS sebagai lembaga yang berwenang melakukan pengelolaan zakat secara nasional. Dalam UU tersebut, BAZNAS dinyatakan sebagai lembaga pemerintah nonstruktural yang bersifat mandiri dan bertanggung jawab kepada Presiden melalui Menteri Agama. Dengan demikian, BAZNAS dengan Pemerintah bertanggung jawab untuk mengawal pengelolaan zakat yang berasaskan syariat Islam, amanah, kemanfaatan, keadilan, kepastian hukum, terintegrasi dan akuntabilitas.

Melihat dari sebagian besar penduduk Indonesia yang mayoritas menganut agama Islam maka sesungguhnya zakat merupakan sector ekonomi yang memiliki potensi untuk dikembangkan. Meski demikian, upaya untuk menggali potensi dan optimalisasi peran zakat di Indonesia belum sepenuhnya tergarap dengan maksimal karena peran zakat belum terlaksana secara efektif dan efisien. Banyak factor yang menyebabkan manfaat dari zakat ini belum terasa maksimal, diantaranya adalah lemahnya motivasi keagamaan dan kesadaran keislaman pada mayoritas masyarakat sehingga rendahnya kesadaran masyarakat dalam menunaikan kewajiban membayar zakat, kurangnya pengawasan dari lembaga-lembaga pengelola zakat dalam pendistribusian zakat sehingga mungkin pihak-pihak yang semestinya mendapatkan zakat tidak mendapatkan haknya, zakat itu diberikan kepada delapan golongan jangan hanya diberikan kepada golongan fakir dan miskin saja, zakat yang diberikan kepada para mustahik sebagian besar digunakan untuk konsumsi sesaat sehingga tidak terjadi kegiatan ekonomi yang bisa mengembangkan harta si mustahik, dan seharusnya zakat yang diberikan oleh muzakki kepada mustahik jangan hanya dalam bentuk uang tetapi juga dalam bentuk modal usaha dan beasiswa pendidikan.

Membangun sebuah sistem pengentasan kemiskinan berbasis zakat tentu tidaklah mudah, perlu adanya kerja sama dengan berbagai pihak untuk memaksimumkan peran zakat dalam mengentaskan kemiskinan. Tugas ini bukan hanya menjadi tanggung jawab pemerintah dan lembaga-lembaga yang mengelola zakat, tapi ini adalah tanggung jawab kita bersama sebagai seorang muslim untuk mensejahterakan muslim lain yang kekurangan. 
Pembangunan sistem pengelolaan zakat yang melibatkan struktur kemasyarakatan yang paling dekat dengan masyarakat itu sendiri harus tetap dikerjakan dan dikembangkan walaupun membutuhkan waktu yang tidak singkat. Menggali dan mengembangkan potensi zakat memang membutuhkan waktu yang panjang tetapi masyarakat harus optimis bahwa sistem zakat ini mampu memberikan solusi bagi masalah kemiskinan yang sudah berlarut-larut. Potensi zakat yang sudah ada harus tetap dipertahankan dan kesadaran untuk membayar zakat harus semakin ditingkatkan sehingga peran zakat dalam proses mengentaskan kemiskinan menjadi semakin diakui dan mendapat kepercayaan dari masyarakat luas.

Potensi dan peran zakat yang ada diharapkan menjadi sarana untuk mengentaskan kemiskinan dan mendapatkan perhatian besar, penuntasan penanggulangan kemiskinan harus segera dilakukan dan zakat di harapkan memiliki sumbangsi kepada kaum miskin khususnya yang membutuhkan perhatian dari semua pihak. Seperti usaha yang di lakukan dalam pengembangan potensi zakat melalui upaya Pinjaman Modal Usaha, Pembibitan Ikan, Pembibitan Pertanian, Peternakan, dan Pendayagunaan zakat fakir miskin untuk Pemberdayaan Keluarga Muslim dan pelatihan serta keterampilan agar nantinya masyarakat miskin memiliki bekal berupa pengalaman yang dapat digunakan untuk merubah hidupnya menjadi lebih baik. Sebagai pendekatannya digunakan metode deskriptif analisi, menurut Wasty Soemanto dalam (Samsul et al., 2019) merode deskriptif yaitu cara penulisan dengan mengutamakan pengamatan terhadap gejala, peristiwa dan kondisi actual dimasa sekarang, maksudnya yaitu deskriptif berarti menggambarkan, analisis berarti menguraikan.

\section{Metode Penelitian}

Penelitian ini merupakan jenis penelitian library research (penelitian kepustakaan). Penelitian kepustakaan yaitu penelitian yang menggunakan data-data tertulis seperti buku, kitab, majalah, jurnal, surat kabar, dan lain-lain. Menurut Hadari Nawawi dalam (Samsul et al. 2019), metode penelitian atau metodologi research adalah ilmu yang memperbincangkan tentang metode-metode ilmiah dalam menggali kebenaran pengetahuan.

Metode pengumpulan data dalam penelitian ini menggunakan metode studi pustaka, yaitu pengumpulan data sekunder dengan mengumpulkan dan mempelajari informasi yang diperoleh dari buku-buku terkait, jurnal, website dan artikel.

Analisis data yang digunakan adalah analisis data kualitatif, yaitu data yang tidak bisa diukur atau dinilai dengan angka secara langsung. Analisis data kualitatif adalah upaya yang dilakukan dengan jalan bekerja dengan data, mengorganisasikan data, memilah-milahnya menjadi satuan yang dapat dikelola, mensintesiskan, mencari dan menemukan pola, menemukan apa yang penting dan apa yang dipelajari dan memutuskan apa yang dapat diceritakan kepada orang lain.

\section{Hasil dan Analisis}

\subsection{Zakat Dalam Perspektif Sosial dan Ekonomi}

Dalam istilah ekonomi, zakat merupakan suatu tindakan pemindahan harta kekayaan dari golongan yang kaya kepada golongan miskin. Transfer kekayaan berarti juga transfer sumber- 
sumber ekonomi. Rahardjo (1987) menyatakan bahwa dengan menggunakan pendekatan ekonomi, zakat bisa berkembang menjadi konsep kemasyarakatan (muamalah), yaitu konsep tentang bagaimana cara manusia melakukan kehidupan bermasyarakat termasuk di dalamnya bentuk ekonomi. Oleh karena itu ada dua konsep yang selalu di kemukakan dalam pembahasan mengenai sosial ekonomi Islam yang saling berkaitan yaitu pelarangan riba dan perintah membayar zakat (Q.S al-Baqarah/2:276).

(Amalia, 1999) Zakat ditinjau dari pendekatan etnis dan pemikiran rasional ekonomis adalah sebagai kebijaksanaan ekonomi yang dapat mengangkat derajat orang-orang miskin, sehingga dampak sosial yang diharapkan dapat tercapai secara maksimal. Hal ini dapat terwujud apabila dilakukan pendistribusian kekayaan yang adil.

(Amalia, 1999) Zakat mungkin didistribusikan secara langsung kepada orang-orang yang berhak, baik kepada satu atau lebih penerima zakat maupun kepada organisasi sosial yang mengurusi fakir miskin. Namun hendaknya kita mencari orang-orang yang benar membutuhkan. Untuk menghindari pemberian zakat kepada orang yang salah, maka pembayar zakat hendaknya memastikan dulu. Dalam kitab hukum fiqh Islam, harta kekayaan yang wajib dizakati digolongkan dalam kategori:
a. Emas, perak dan uang (simpanan)
b. Barang yang diperdagangkan
c. Hasil peternakan
d. Hasil bumi
e. Hasil tambang dan barang temuan

\subsection{Peran dan Pengelolaan Zakat Terhadap Kemiskinan}

Peran dan Pengelolaan Zakat Terhadap Kemiskinan Zakat dianggap mampu dalam pengentasan kemiskinan, karena zakat merupakan sarana yang dilegalkan agama dalam pembentukan modal. Pembentukan modal semata-mata tidak hanya berasal dari pengolahan dan pemanfaatan sumber daya alam saja, tetapi melalui upaya penyisihan sebagian harta bagi yang mampu, yang wajib di bayarkan kepada pengelola zakat. Zakat di anggap akan mampu memaksimalkan kualitas SDM melalui pengadaan sarana dan prasarana bagi masyarakat, meningkatkan produktifitas, serta meningkatkan pendapatan masyarakat secara umum.

\subsection{Pengaruh Zakat Terhadap Kemiskinan}

Jika dilihat Indonesia merupakan Negara yang memiliki jumlah umat muslim terbesar di dunia harus memiliki peran aktif dalam perwujudan kesejahteraan masyarakat dengan pengoptimalan potensi zakat. Potensi ini tentu saja di anggap jelas mampu mewujudkan pengentasan kemiskinan, tetapi melalui pengelolaan dan mekanisme yang tepat dan mempunyai hasil baik. Potensi zakat yang bisa di kembangkan untuk mengentaskan kemiskinan adalah zakat yang memiliki sifat produktif.

Zakat produktif adalah pemberian zakat yang dapat membuat para penerimanya menghasilkan sesuatu secara terus menerus, dengan harta zakat yang telah diterimanya. Dengan kata lain zakat dimana harta atau dana zakat yang diberikan kepada para mustahik tidak di habiskan akan tetapi dikembangkan dan di gunakan untuk membantu usaha mereka, 
sehungga dengan usaha tersebut mereka dapat memenuhi kebutuhan hidup secara terusmenerus.

Pendayagunaan zakat produktif melalui cara atau usaha dalam mendatangkan hasil dan manfaat yang lebih besar serta lebih baik. Pemanfaatan zakat harta sangat tergantung pada pengelolahnya. Apabila pengelolaannya baik, pemanfaatannya akan dirasakan oleh masyarakat. Pemanfaatan zakat ini, biasanya berbeda dari satu daerah kedaerah lain. Dari penelitian lapangan yang dilakukan diketahui bahwa pada umumnya bahwa penggunaan zakat harta diantaranya untuk pemberdayaan ekonomi masyarakat seperti; dipergunakan untuk usaha pertanian, peternakan dan usaha kecil lainnya.

\section{Kesimpulan}

Zakat Dalam Perspektif Sosial dan Ekonomi Dalam istilah ekonomi, zakat merupakan suatu tindakan pemindahan harta kekayaan dari golongan yang kaya kepada golongan miskin.

Zakat mungkin didistribusikan secara langsung kepada orang-orang yang berhak, baik kepada satu atau lebih penerima zakat maupun kepada organisasi sosial yang mengurusi fakir miskin.

Peran dan Pengelolaan Zakat Terhadap Kemiskinan Peran dan Pengelolaan Zakat Terhadap Kemiskinan Zakat dianggap mampu dalam pengentasan kemiskinan, karena zakat merupakan sarana yang dilegalkan agama dalam pembentukan modal.

Zakat produktif adalah pemberian zakat yang dapat membuat para penerimanya menghasilkan sesuatu secara terus menerus, dengan harta zakat yang telah diterimanya.

Dengan kata lain zakat dimana harta atau dana zakat yang diberikan kepada para mustahik tidak di habiskan akan tetapi dikembangkan dan di gunakan untuk membantu usaha mereka, sehungga dengan usaha tersebut mereka dapat memenuhi kebutuhan hidup secara terusmenerus.

\section{Referensi}

Amalia, K. M. A. (1999). POTENSI DAN PERANAN ZAKAT DALAM MENGENTASKAN KEMISKINAN DI KOTA MEDAN Amalia, Kasyful Mahalli. Jurnal Ekonomi Dan Keuangan, 1(1), 70-87.

Handayani, N. (2020). Pengaruh Pendayagunaan Zakat Terhadap Pemberdayaan Mustahik di BAZNAS Kabupaten Enrekang. Skripsi, 11. http://repository.iainpare.ac.id/id/eprint/1513 